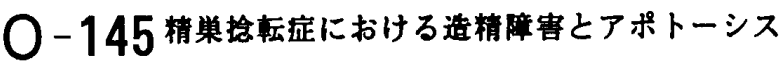

豊川市民”，名古屋市立大学”

梅本幸裕" · 伊藤尊一郎" ・津ヶ谷正行"

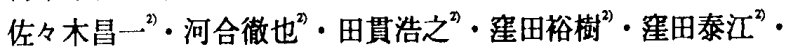
山本洋人” $\cdot$ 神谷浩行 ${ }^{n} \cdot$ 郡 健二郎”

【目的】精巣捻転症は6時間以上経てからの整復は造精障害 を免れ得ないと言われ、また若年ほど障害が少ないと言われ る。この機序に対するアポトーシスの関与を検討した。【方 法] 3、6、10週龄のWistar 系雄ラットの左精索を結禁し、6、 12、24時間後に結禁解除後、1日、3日、5日、1週および5週 後に両側精巣を摘出した。これをH-E染色とアポトーシス細 胞検出のためにTUNEL染色をした。【結果】患側精巣は6時 間の虚血ではどの週龄でも造精能の回復がみられたか、12時 間以上では荒廃していた。健側精巣は6、10週踰の虚血12時 間以上において軽度の造精障害がみられた。患㑡は虚血1日 後からTUNEL染色陽性細胞が出現し、5日目までは造精障害 の悪化とともに增加して、その回復とともに減少した。一方 回復しなかった精巣はアポトーシス細胞が著明に増加した。

【まとめ】造精機能は6時間の虚血までは回復したがそれ以 上では耑廃した。健側精巣は成熟したラットでは障害されや すかった。また虚血による造精障害にはアポトーシスが関与 していると考えられた。

\section{O-147 新涽インポテンスの检討}

\author{
中部労災 1 西尾市民每

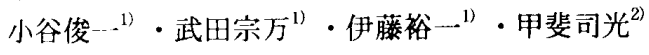

【目的】新婚インポテンス患者の臨床的特徽と取り 扱い上の注意を検捨した。【対象】1985.1〜1997.10 の新婚インポテンス 96 名(初めから明らかに器質性イン ポテンスと判断できる例は除外）を対象。年齢24から 51 歳（平均 34.3 歳）、初婚 92 名、離婚後再婚 4 名。結 婚動機计恋愛結婚23名、見合门結婚63名、不明10名。 41名（43\%）が実子希望。【検查結果】46名でリジス キャンモニター（正常 41 名 $89 \%$ )を、85名でPGE1テ スト（正常75名88\%）を施行した。この結果68名（71 \%) は心因性インポテンス、4名（4\%）は精神病性イ ンポテンス、6名 $(6 \%)$ は器質性インポテンス、残る 18名は診断不能。【治療】陰圧式勃起補助用具を 26 名、 PGE1トレーニング15名、PGE1自己注射9名、カウン セリング7名。この内16名が性交可能となった。【結論】 新婚インポテンスの中にも数\%の器質性インポテンス が含まれる可能性があり十分な性機能検查が重要であ る。放置すると離婚にいたる可能性があるため、治療 は早急にしたほうが良い。特に自己注射法は有用。

\section{O-146 アルコール負荷による夜周轨起現家の模时}

旭川医科大学

谷口成実・加藤祐司 - 本谷 匡 - 池田和彦 - 岩田達也 ·

水永光博・宮田昌伸・金子茂男 $\cdot$ 八竹 直

【目的】勃起機能に及ぼすアルコールの急性効果あるいは夜 間勃起現象の連続記録に及ぼす晚酌の影嘼については、十分 に検討されていない。本研究においては、アルコール摃取の 夜間陰茎勃起現象に対する急性効果を、RIGISCAN" を用い て検討した。

【方法】対象は、インフォームドコンセントを得られたボラ ンティアの健常男性 8 名（年齢 25 才から49才）である。 コントロールとして、飲酒しない状態で二晚 RIGISCAN"を 用いて、夜間勃起現象を観察し、翌晚䄪 2 リットル以上のビ 一ルあるいはそれに相当するアルコール飲料を摂取させ、夜 間勃起現象を観察記録した。データーは、RIGISCANPlus 付 属の windows 版解析プログラムを用いた。計測したパラメ ターは、波形の変化、一晚の勃起回数とその持続時間、さら に tip と base の勃起時の平均の硬度、周径などである。また、 RIGISCAN ${ }^{2}$ 装着前に、血中アルコール䈨度を測定した。

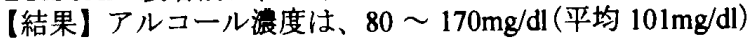
と大きなばらつきはなく、いわゆる酩酊に近い状热であった。 アルコール負荷時は、コントロールに比べ勃起回数、持続時 間には差は見られなかったが、tip、base ともに硬度、周径 の平均値が低下する傾向を認めた。アルコール負荷時の波形 は、一回の周径增大現象の中で硬度が持続せず変動するパタ ーンが特徴的であった。

【まとめ】アルコールにより夜間の勃起現象は、勃起回数と 時間には影䣔なかったが、硬度と周径の低下を認めた。

\section{O-148 泌尿器監惠患者のインポテンスに対するアル プロスダル経尿道投与の使用経的}

知多市民病院1)。藤田保健衛生大学2)。長久保クリニック3) 花井俊典 1)、永 裕彰1)、堀場優樹2)、星长清隆 2)、 名出頼男2)、長久保一朗3)、桜井孝彦3)、竹内昭雄 3 )

インポテンスの治療に関しては、従来から様々な試みがな されてはいるものの、簡便かつ著明な有効性が報告されてい るものはない。米国ではすでにプロスタグランジンの経尿道 投与が施行され、高い有効率が報告されている。

今回、我々は、アルプロスタジルを使用する機会を得たの で、膀胱癌、前立腺癌患者の治療に基ずくインポテンスに対 して使用したところ、良好な成績を得たので報告する。

対象は膀腃全摘術後 4 例、前立腺全摘術後 2 例、前立腺灌 内分泌療法施行中 1 例の合計 7 例で、平均年齢は 52.7 歲で あった。治療までの平均䍜患期間は 27.3 ケ月であった。

本剤の効果は、不完全な勃起 5 例（71.4\%）、完全勃起 2 例 (28.6\%) であり、全例が性交可能であった。勃起ま での時間は 10 分以内 5 例、 20 分以内が 2 例であった。勃 起持続時間は 5 分間から 2 時間までとかなりのばらつきがみ られた。

副作用としては 1 例に勃起時の陰茎根部の疼痛がみられた が、性交の障害とはならなかった。

以上より本剤は患者自身が投与のタイミングを選択でき、 手技が簡便であることからインポテンスの新しい治療楽とし て画期的なものと考えられた。 